\title{
THE DOCUMENT: Ten Theses on New Developmentalism
}

In May 24 and 25 of 2010, a group of economists sharing a Keynesian and structuralist development macroeconomics approach got together in São Paulo to discuss ten theses on New Developmentalism - the name that some of them have been using for some years to design the national development strategy that middle income countries are today using or are supposed to adopt for catching up. They summarize a theoretical and policy alternative to conventional orthodoxy. The New Developmentalism Project, financed by the Ford Foundation, has as background the failure of the Washington Consensus to promote growth in Latin America and the 2008 Global Financial Crisis that showed the limits and dangers involved in financial globalization and financial deregulation. The general objective of the workshop was to analyze the repeated financial crises in middle income developing countries and 2008 global financial crisis, and to evaluate how effective can be the new developmentalist strategy to assure growth with stability; the specific one was to discuss the ten theses on new developmentalism previously presented to the participants: theses that supposedly avoid financial crises and bolster growth rates.

After two days of vivid discussion, the local organizers of the workshop were charged of editing the theses to reflect the views of the participants expressed in the debates and in the following e-mail discussion. This is the final document that the original participants subscribed and immediately after invited a number of other economists and social scientists committed with the idea of economic growth with stability and social equity.

Economic development is a structural process of capital accumulation with incorporation of technical progress that involves not only the increase of productivity in each industry but also the continuous transference of labor to industries producing goods and services with higher value added per-capita and paying higher wages and salaries. In the case of developing countries this is particularly true because they are characterized by structural heterogeneity.

Although markets play a major role, the state is supposed to have a strategic role on the macro level assuring investment opportunities (satisfactory expected rates of profit), keeping inflation and public debt under control and the financial system stable, and, on the micro level, implementing a strategic industrial policy. State intervention should be primarily counter-cyclical at the macro-level.

In the framework of globalization, economic development requires a national 
development strategy, i.e., an informal cluster of objectives, understandings and policies that increase profit expectations, stimulate investment, and achieve growth and full employment with price, financial stability and income distribution.

Although the supply side of economic development and a strategic industrial policy are relevant, the demand side is where the major growth bottlenecks are. Besides the fact well established since Keynes that the supply does not automatically create demand, there are two structural tendencies that limit demand and, so, investment opportunities: the cyclical tendency of wages to increase below the growth of the productivity, and the tendency to the overvaluation of the exchange rate.

The tendency of wages to increase below the growth of productivity is due to the existence of an unlimited supply of labor. The definition of a minimum wage and a system of cash and benefits transfers to the poor should be part of the policies neutralizing this tendency that undervalues labor. The alternative - chronic overvaluation of the national currency - is not a sustainable alternative.

The tendency to the cyclical overvaluation of the exchange rate in developing countries is mainly due to the Dutch disease and the attempt to grow with foreign savings (current account deficits financed by capital inflows) and national indebtedness. This tendency implies that the exchange rate in developing countries is not just volatile around the current market equilibrium, but checked by currency crisis or sudden stops. It also implies that export oriented investment opportunities are chronically insufficient in these countries in so far that efficient business enterprises turn uncompetitive internationally.

The Dutch disease is a permanent overvaluation of the national currency due to Ricardian rents originated by the export of commodities based on natural resources (or cheap labor combined with a large salary-wage dispersion) that impede that other tradable industries utilizing technology in the world state of the art are competitive in so far as it creates a divergence between the "current equilibrium exchange rate" (the one that balances intertemporally the current account) and the "industrial equilibrium exchange rate" — the one that allows tradable industries to be competitive utilizing technology in the world state-of-art.

Economic development is supposed to be financed essentially with domestic savings; the creation of public financial institutions to finance investment is recommended. The attempt to use foreign savings or to recur to current account deficits usually does not increase the investment rate (as it is supposed to do), but domestic consumption; it usually implies a high rate of substitution of foreign for domestic savings. The growth with foreign savings policy, first, causes this substitution; second, causes financial fragility and the constraint to get involved in the "confidence building" game; and, eventually, ends into a balance of payment or currency crisis.

In order to achieve financial and price stability (low inflation), government is supposed to prove fiscal responsibility (long term budget deficit that keep the relation between public debt and GDP in a satisfactory level) and exchange rate responsibility (a real exchange rate that is supposed to correspond to the industrial equilibrium level).

To achieve growth with stability, fiscal and monetary policies should pursue clear employment, inflation and exchange rate targets that are compatible with 
growth with domestic savings and the neutralization of the tendencies to the increase of wages below the productivity rate of growth and to the overvaluation of the exchange rate. With these three objectives in mind, policymakers should adopt a large collection of policy instruments that should include the management of the interest rate around a moderate level, increase in foreign reserves, capital controls, and exports taxes on Dutch disease commodities. And society as a whole should develop a welfare system that reduces inequality and is anti-cyclical.

São Paulo, September 29, 2010

\section{Original subscribers}

Agosin, Manuel

Amsden, Alice

Arestis, Phillip

Baer, Werner

Belluzzo, Luiz Gonzaga

Bhaduri, Amit

Bielschowsky, Ricardo

Blecker, Robert

Block, Fred

Boyer, Robert

Bresser-Pereira, Luiz

Carlos

Bruno, Miguel

Bruszt, Laszlo

Burlamaqui, Leonardo

Carneiro, Ricardo

Carvalho, Fernando

Cardim de

Chandrasekhar, C. P.

(Chandru)

Chang, Ha-Joon

Chavagneux, Christian

Chick, Victoria

Chilcote, Ronald

Coutinho, Luciano

Damill, Mario

Davidson, Paul

Dymski, Gary
Dulien, Sebastian

Dutt, Amitava

Epstein, Gerald

Faucher, Philippe

Ferrari, Fernando

Ferrer, Aldo

Frenkel, Roberto

Gala, Paulo

Galbraith, James

Gallagher, Kevin

Garcia, Norberto E.

Ghosh, Jayati

Girón, Alicia

Guillén, Arturo

Guttmann, Robert

Huber, Evelyne

Jomo, K. S.

Kregel, Jan

Kupfer, David

Lazonick, William

Le Heron, Edwin

Lopez, Julio

Marco Del Pont,

Mercedes

Marconi, Nelson

Mazier, Jacques

Nakano, Yoshiaki

Nayyar, Deepak
O'Connell, Arturo

Ocampo, José Antonio

Oreiro, José Luis

Palley, Thomas I.

Palma, Gabriel

Papadimitriou, Dimitri

Paula, Luiz Fernando de

Petit, Pascal

Popov, Vladimir

Prates, Daniela

Przeworski, Adam

Punzo, Lionello

Rapetti, Martin

Reinert, Erik S.

Ros, Jaime

Rueschemeyer, Dietrich

Salama, Pierre

Saywer, Malcolm

Schneider, Ben Ross

Serrano, Franklin

Stephens, John

Sunkel, Osvaldo

Taylor, Lance

Vernengo, Matias

Wade, Robert

Weisbrot, Mark

Weiss, Linda

Wray, Randall 